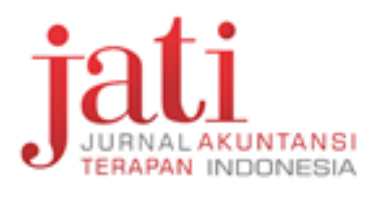

Jurnal Akuntansi Terapan Indonesia Vol 4 No 1 Hal 1-13 March 2021

Affiliation:

Universitas Negeri Malang, Indonesia

*Correspondence:

vitmiasih@gmail.com

This Article is Avalilable in:

https://journal.umy.ac.id/index.

php/jati/article/view/9255

DOI:

https://doi.org/10.18196/jati.v4i1.925 5

Citation:

Vitmiasih, V., Maharani, S., \& Narullia, D. (2021). Pengambilan Keputusan Investasi Rasional: Suatu Tinjauan dari Dampak Perilaku Representativeness Bias dan Hearding Effect. Jati: Jurnal Akuntansi Terapan Indonesia, 4(1), 113.

Article History

Received:

22 July 2020

Reviewed:

08 September 2020

Revised:

02 October 2020

Accepted:

30 January 2021

Topic Article:

Behavioral Accounting

\section{Pengambilan Keputusan Investasi Rasional: Suatu Tinjauan dari Dampak Perilaku Representativeness Bias dan Hearding Effect}

\author{
Vitmiasih*1, Satia Nur Maharani², Dwi Narullia $^{3}$
}

\begin{abstract}
:
The aim of this study was to determine the effect of representation bias and herding behavior towards rational investment decision making, which was detected using the Heuristic Theory perspective on the Investor Saham Pemula (ISP) community in East Java. This research uses a mixed-method by using a sequential explanatory strategy. This study uses primary data obtained by distributing online questionnaires in 10 cities in East Java and interviews with expert practitioners. The sample of this research is 111 active investors who trade independently. In relation, the data analysis was through multiple linear regression. This research succeeded in proving that representative bias behavior has a negative influence on decision-making on rational investment. On the other hand, no evidence showed the effect of herding behavior influencing investment decision making. The phenomenon indicates that investors rely more on information obtained through the results of their own reason rather than following the decisions of other investors.
\end{abstract}

Keywords: Representativeness Bias, Herding-Effect Behavior, Heuristic Theory

Abstrak:

Penelitian ini bertujuan untuk menganalisa pengaruh representativeness bias dan herding behavior terhadap pengambilan keputusan investasi yang rasional yang dideteksi dengan menggunakan perspektif Teori Heuristik pada komunitas Investor Saham Pemula (ISP) di Jawa Timur. Penelitian ini menggunakan metode campuran dilengkapi dengan strategi penjelas berurutan. Studi penelitian ini menggunakan data primer yang diperoleh dengan menyebarkan kuesioner online di 10 kota di Jawa Timur dan wawancara dengan praktisi ahli. Sampel penelitian ini adalah 111 investor aktif yang berdagang secara mandiri. Dalam kaitannya, analisis data dilakukan melalui regresi linier ganda. Penelitian ini berhasil membuktikan bahwa perilaku representativeness bias berpengaruh negatif terhadap pengambilan keputusan atas investasi rasional. Di sisi lain, tidak ada bukti yang menunjukkan pengaruh herding behavior mempengaruhi pengambilan keputusan investasi. Fenomena tersebut mengindikasikan bahwa investor lebih mengandalkan informasi yang diperoleh melalui hasil nalar pribadi dibandingkan mengikuti keputusan investor lain.

Kata Kunci: Representativeness Bias, Perilaku Herding-Effect, Teori Heuristic

\section{PENDAHULUAN}

Teori keuangan tradisional merupakan teori yang menjelaskan bagaimana seharusnya manusia berperilaku, John Stuart Mill (1806-1873) menggambarkan manusia sebagai homo 
economicus yang secara konsiten berperilaku rasional dalam membuat keputusan keuangan (Hinnant, 1998). Berdasarkan teori tersebut dapat dikatakana bahwa manusia akan mengumpulkan berbagai informasi untuk membuat keputusan keuangan yang rasional. Informasi yang relevan membuat investor dapat mengukur nilai perusahaan secara rasional (Narullia, Subekti, Azizah, \& Purnamasari, 2019; Narullia \& Subroto, 2018). Menurut Scott (2015) investor memiliki keinginan untuk membuat prediksinya sendiri terkait dengan pengembalian investasi di masa depan sehingga investor akan berupaya mengumpulkan dan memproses semua informasi untuk mencapai tujuan tersebut. Ketika menerima informasi baru, investor rasional akan berupaya merubah keyakinan awalnya terhadap expected value saham terkait dan membuat keputusan investasi berdasarkan keyakinan yang telah dibentuk. Asumsi perilaku rasional pada teori keuangan tradisional tersebut melekat pada karakteristik investor yang dinyatakan dalam Efficient Market Hypothesis (Fama, 1970). Fama (1970) mengemukakan bahwa dalam pasar efisien, kinerja saham mampu menggambarkan seluruh informasi yang tersedia secara penuh dan cepat. Informasi yang didistribusikan ke dalam pasar dimanfaatkan investor sebagai sumber analisis fundamental, dimana dari aktivitas tersebut dapat mendorong perubahan nilai instrinsik saham beserta harga saham bersangkutan.

Faktanya, keberadaan pasar seperti yang digambarkan pada Efficient Market Hypothesis tidak sepenuhnya berjalan di pasar modal. Terdapat kondisi dimana pelaku pasar tidak dapat mencerna informasi yang tersedia secara rasional, sehingga hal ini menyebabkan pasar bekerja menyimpang dari aturan-aturan logis pasar modal. Salah satu contoh fenomena yang menyebabkan pasar modal menjadi tidak efisien seperti dikutip dalam CNN Indonesia adalah krisis keuangan yang menimpa negara Turki. Menurut Darmin Nasution selaku Menteri Koordinator bidang Perekonomian, melemahnya nilai tukar lira dan peningkatan bea masuk atas impor Turki oleh Amerika Serikat berdampak secara psikologi terhadap pasar modal dan mata uang negara berkembang, termasuk negara Indonesia (Gumelar, 2018). Rendahnya performa perekonomian ini menyebabkan investor menjadi panik dan berusaha mengalihkan portofolio investasinya dari Turki dan negara-negara berkembang lainnya.

Perilaku investor dinilai terlalu berlebihan dalam menanggapi krisis Turki. Darmin menyatakan bahwa krisis tersebut terjadi karena adanya sentimen pribadi Amerika Serikat terhadap Turki, sehingga apabila kejadian ini disikapi dengan bijak maka krisis tersebut tidak berdampak pada negara-negara berkembang lainnya. Reaksi berlebihan ini pada akhirnya berimbas terhadap penurunan IHSG sesi I pada 13 Agustus 2018 sebesar 3,29 persen menuju 5.877 (Gumelar, 2018). Investor melakukan aksi jual secara berlebihan karena adanya kekhawatiran jika peristiwa tersebut dapat mendatangkan kerugian pada portofolio investasinya, akan tetapi persepsi ini tidak didukung dengan analisis informasi yang akurat. Hal ini mengakibatkan harga saham tidak lagi menggambarkan informasi yang tersedia, melainkan merupakan manifestasi dari faktor psikologi dan emosi investor secara kolektif.

Kesenjangan yang timbul antara teori dan bukti lapangan menyebabkan Efficient Market Hipothesis tidak lagi dapat secara akurat berkontribusi dalam menggambarkan pergerakan harga saham di pasar modal. Kenyataan tersebut kemudian mendorong berkembangnya paradigma Behavioral Finance yang mencoba menganalisis bias psikologi investor yang belum terakomodasi dalam Efficient Market Hipothesis. Kim \& Nofsinger (2008) beranggapan bahwa Behavioral Finance merupakan pendekatan yang lebih layak untuk menjelaskan bagaimana partisipan pasar dalam membuat keputusan keuangan dan pada gilirannya, implikasi tindakan tersebut terhadap pasar modal. Pendekatan ini dibangun atas asumsi bahwa pelaku pasar tidak sepenuhnya bertindak rasional. Hal tersebut diperkuat dengan pendapat Statman (2014) bahwa dalam menentukan keputusan keuangan, investor tidak terlepas dari adanya pengaruh kesalahan kognitif dan emosi yang menyesatkan. 
Behavioral finance merupakan studi yang mempelajari dampak psikologi kognitif terhadap proses pengambilan keputusan investasi. Kognisi manusia pada dasarnya memiliki kapasitas yang terbatas. Sehingga, ketika individu menerima informasi terlalu banyak, maka dalam kondisi tersebut dapat terjadi kejenuhan informasi dimana sistem kognitif dituntut untuk bekerja lebih keras daripada yang dapat dilakukan (Baron \& Byrne, 2004). Untuk mengurangi usaha mental saat memproses informasi, pengambilan keputusan seringkali mengandalkan strategi jalan pintas sebagaimana yang dijelaskan dalam Heuristic Theory. Heuristic merupakan jalan pintas atau aturan sederhana yang membuat pengambilan keputusan menjadi lebih mudah terutama dalam situasi dan konsdisi yang kompleks dan tidak pasti (Kahneman \& Tversky, 1979; Tversky \& Kahneman, 1974, 1992). Heuristic mental shortcut bekerja dengan cara mereduksi kompleksitas suatu fenomena menjadi operasi penilaian yang lebih sederhana.

Salah satu bentuk perilaku bias yang dijelaskan pada Heuristic Theory adalah representativeness bias. Maharani (2014) mendefinisikan representativeness bias sebagai perilaku individu yang mengelompokkan peristiwa atau situasi baru berdasarkan pengalaman masa lalu, meskipun pada kenyataannya berbeda. Perilaku ini terbentuk karena individu seringkali dihadapkan pada peristiwa serupa, sehingga penyelesaian masalah yang dilakukan dianggap relatif sama. Ketika individu dipaksa untuk merumuskan penilaian di bawah situasi dan kondisi yang tidak pasti, maka pengambilan keputusan dilakukan hanya berdasarkan informasi yang dapat mewakili fenomena terkait (Tversky \& Kahneman, 1974). Informasi ini secara sederhana diperoleh dengan mengaktivasi skema yang telah dibangun dalam ingatan investor dan menyamakannya dengan situasi saat ini (Baron \& Byrne, 2004).

Penelitian mengenai pengaruh representativeness bias terhadap pengambilan keputusan investasi telah dilakukan oleh Dewi \& Kartini (2017) pada investor di wilayah Yogyakarta. Hasil penelitian ini membuktikan bahwa investor cenderung yakin saham baik berasal dari perusahaan yang memiliki laba historis stabil. Penelitian serupa juga dilakukan oleh Trang (2015) pada investor yang terdaftar pada Ho Chi Minh Stock Exchange Vietnam dan menunjukkan hasil bahwa representativeness bias mendorong investor tidak berinvestasi pada saham dengan kinerja masa lalu buruk untuk menghindari kemungkinan terjadinya kerugian. Hasil yang berbeda ditunjukkan dalam penelitian yang dilakukan oleh Hadi (2017) pada investor, analis keuangan, dan sarjana keuangan di Islamabad, dimana representativeness bias tidak mempengaruhi pengambilan keputusan investasi.

Heuristic Theory juga menjelaskan pengambilan keputusan investasi yang dipengaruhi oleh faktor lingkungan yakni herding effect. Ghalandari \& Ghahremanpour (2013) menyatakan bahwa herding effect adalah kecenderungan investor meniru keputusan investor lain. Herding mentality rentan dialami pelaku pasar ketika kondisi pasar sedang tidak pasti, terutama pada investor yang hanya memiliki pengetahuan dan informasi rendah. Kondisi ini menyebabkan investor cemas apabila keputusan yang diambil secara individu dapat mendatangkan kerugian. Menurut Gupta, Preetibedi, \& Mlakra (2014) perilaku herding didorong oleh adanya anggapan bahwa keputusan yang diambil oleh mayoritas investor tidak mungkin salah.

Penelitian Ngoc (2014) menunjukkan bahwa investor yang dipengaruhi herding effect cenderung memperhatikan keputusan yang dilakukan investor lain. Hasil tersebut senada dengan penelitian yang dilakukan oleh Bhatt \& Pahuja (2016) pada investor individu di kota Udaipur dan membuktikan bahwa perilaku herding effect menyebabkan investor bereaksi dengan cepat terhadap setiap perubahan keputusan investasi yang diambil oleh investor lain. Di sisi lain, penelitian yang dilakukan oleh Bakar \& Yi (2016) pada investor di Malaysia tidak menemukan bukti adanya pengaruh herding effect terhadap pengambilan keputusan investasi. 
Penelitian-penelitian terdahulu terkait dengan pengaruh representativeness bias (Dewi \& Kartini, 2017; Hadi, 2017; Trang, 2015) dan herding effect (Bakar \& Yi, 2016; Bhatt \& Pahuja, 2016; Ngoc, 2014) terhadap pengambilan keputusan investasi memberikan hasil yang berbeda-beda. Pada penelitian ini, penulis ingin menguji ulang pengaruh kedua variabel tersebut pengambilan keputusan investasi rasional dipandang menarik untuk dilakukan. Penelitian ini bertujuan untuk menguji pengaruh perilaku representativeness bias dan herding effect terhadap pengambilan keputusan investasi rasional. Keterbaruan dari penelitian ini terletak pada sampel yang digunakan yakni investor yang tergabung dalam komunitas Investor Saham Pemula (ISP) di Jawa Timur. Sampel tersebut dipilih karena investor pemula cenderung memiliki pengetahuan dan pengalaman yang terbatas, sehingga memanfaatkan aturan jalan pintas untuk mempermudah proses pengambilan keputusan. Kurangnya pengalaman yang dimiliki ISP diperkirakan akan mengurangi usaha mental saat memproses informasi, sehingga pengambilan keputusan seringkali mengandalkan strategi jalan pintas sebagaimana yang dijelaskan dalam Heuristic Theory. Wilayah komunitas yang diteliti yaitu Jawa Timur, karena pada tahun 2018 provinsi tersebut menempati urutan ke-3 jumlah investor terbanyak dari 34 provinsi di Indonesia yaitu sebesar 144.766 (Wijayanto, 2018). Berdasarkan kondisi dan keadaan yang telah dijabarkan di atas, maka peneliti mengangkat sebuah topik penelitian dengan judul "Pengaruh Perilaku Representativeness Bias dan Herding Effect terhadap Pengambilan Keputusan Investasi Rasional”.

\section{METODE PENELITIAN}

Penelitian ini menggunakan metode mixed method yakni mengkombinasikan pendekatan kuantitatif dan kualitatif dalam kegiatan penelitian. Penelitian ini menerapkan strategi eksplanatoris sekuensial, yaitu mengumpulkan dan menganalisis data kuantitatif pada tahap awal kemudian mengumpulkan dan menganalisis data kualitatif pada tahap kedua yang dibangun berdasarkan hasil awal kuantitatif (Creswell, 2012) sehingga bobot atau prioritas lebih ditekankan pada data kuantitatif. Berikut adalah kerangka berpikir dalam penelitian ini:

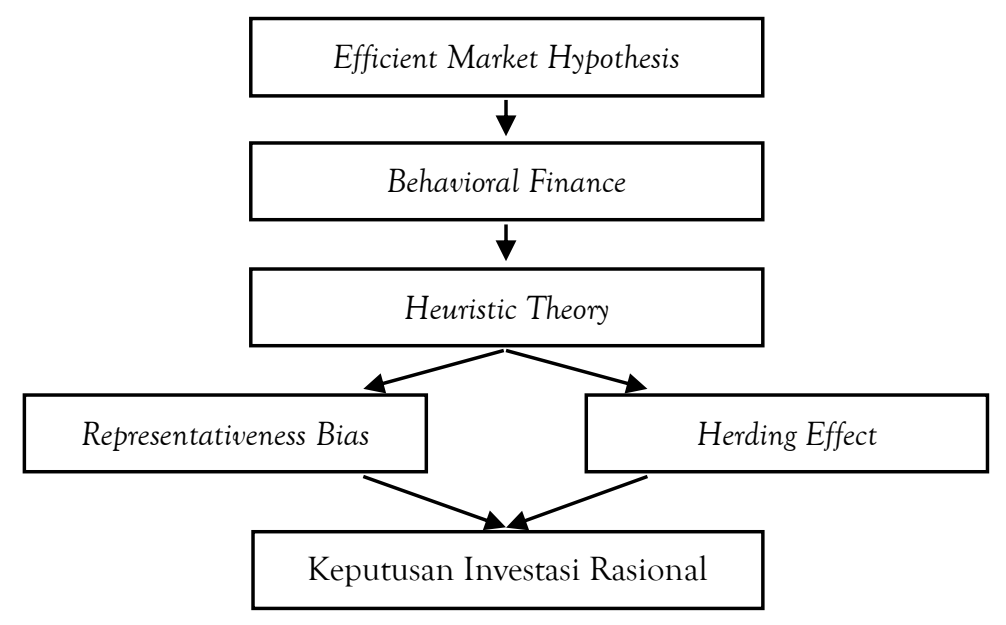

Gambar 1. Kerangka Berpikir Penelitian

\section{Variabel Penelitian}

Studi ini memiliki tiga variabel penelitian yang terdiri dari satu variabel dependen dan dua variabel independen. Variabel pertama yang merupakan variabel dependen yaitu pengambilan keputusan investasi rasional. Pengambilan keputusan investasi rasional merupakan pengambilan keputusan yang dilakukan berdasarkan hasil analisis terhadap 
semua informasi yang tersedia secara logis dan sistematis untuk memperoleh portofolio investasi yang optimal. Pemikiran rasional mendorong individu hanya memilih opsi yang menghasilkan tingkat keuntungan yang paling tinggi serta mampu memenuhi preferensinya. Pernyataan dalam kuesioner ini mengacu pada penelitian terdahulu (Khan, Naz, Qureshi, \& Ghafoor, 2017; Pradhana, 2018; Wulandari \& Iramani, 2014) dengan memodifikasi beberapa butir pernyataan.

Variabel kedua yang merupakan variabel independen yaitu representativeness bias. Representativeness bias adalah kecenderungan investor mengambil keputusan berdasarkan pengalaman masa lalu yang dipersepsikan sama dengan kondisi saat ini. Perilaku bias ini juga dapat didefinisikan sebagai kesalahan dalam membuat keputusan dimana individu menganggap bahwa semakin mirip karakteristik suatu elemen dengan kelompok tertentu, maka semakin mungkin elemen tersebut merupakan bagian dari kelompok. Perilaku representativeness bias diukur dengan beberapa pertanyaan yang diadopsi dari penelitian terdahulu (Chitra \& Jayashree, 2014; Dewi \& Kartini, 2017; Khan et al., 2017; Rasheed, Rafique, Zahid, \& Akhtar, 2018).

Variabel independen selanjutnya adalah herding effect. Herding effect merupakan kecenderungan investor mengikuti keputusan yang diambil oleh investor lain di pasar modal. Perilaku ini umumnya dialami individu yang memiliki sedikit informasi dan pengetahuan, sehingga dengan mengikuti aksi kerumunan massa diharapkan dapat memperoleh pengetahuan dan informasi yang dapat diandalkan. Perilaku herding effect ini diukur dengan menggunakan beberapa pernyataan yang diadopsi dari penelitian terdahulu (Bakar \& Yi, 2016; Gupta et al., 2014; Kengatharan \& Kengatharan, 2014; Manuel \& Mathew, 2017). Adapun jabaran dari pengembangan instrumen penelitian disajikan pada tabel 1 sebagai berikut:

Tabel 1. Jabaran dan Kisi-Kisi Pernyataan

\begin{tabular}{|c|c|c|c|}
\hline No. & Variabel Penelitian & Indikator & No. Butir \\
\hline \multirow[t]{3}{*}{1.} & $\begin{array}{l}\text { Representativeness bias (Chitra } \\
\text { \& Jayashree (2014); Dewi \& }\end{array}$ & $\begin{array}{l}\text { 1. Pengalaman masa lalu poin } 2.1 .4 \\
\text { paragraf 1). }\end{array}$ & $\mathrm{Q}_{1}, \mathrm{Q}_{2}, \mathrm{Q}_{3}$ \\
\hline & $\begin{array}{l}\text { Kartini (2017); Khan dkk. } \\
\text { (2017); Rasheed dkk. (2018)). }\end{array}$ & $\begin{array}{l}\text { 2. Penilaian secara stereotype (poin } 2.1 .4 \\
\text { paragraf } 2 \text { ). }\end{array}$ & $\mathrm{Q}_{4}, \mathrm{Q}_{5}$ \\
\hline & & $\begin{array}{l}\text { 3. Ukuran sampel kecil (poin 2.1.4 } \\
\text { paragraf 3). }\end{array}$ & $Q_{6}$ \\
\hline \multirow[t]{3}{*}{2.} & $\begin{array}{l}\text { Herding effect (Gupta \& } \\
\text { Ahmed (2016); Bakar \& Yi }\end{array}$ & $\begin{array}{l}\text { 1. Meniru keputusan investor lain (poin } \\
\text { 2.1.5 paragraf } 1 \text { ). }\end{array}$ & $\mathrm{Q}_{7}, \mathrm{Q}_{8}, \mathrm{Q}_{9}$ \\
\hline & $\begin{array}{l}\text { (2016); Kengatharan (2014); } \\
\text { Manuel \& Mathew (2017)). }\end{array}$ & $\begin{array}{l}\text { 2. Perlindungan dan kemudahan (poin } \\
\text { 2.1.5 paragraf } 2 \text { ). }\end{array}$ & $\mathrm{Q}_{10}, \mathrm{Q}_{11}$ \\
\hline & & $\begin{array}{l}\text { 3. Herding untuk memperoleh informasi } \\
\text { (poin 2.1.5 paragraf } 3 \text { ). }\end{array}$ & $\begin{array}{l}\mathrm{Q}_{12}, \mathrm{Q}_{13}, \mathrm{Q}_{14} \\
\mathrm{Q}_{15}, \mathrm{Q}_{16}, \mathrm{Q}_{17}\end{array}$ \\
\hline \multirow[t]{3}{*}{3.} & $\begin{array}{l}\text { Keputusan Investasi Rasional } \\
\text { (Khan dkk. (2017); Pradhana }\end{array}$ & $\begin{array}{l}\text { 1. Expected return (poin 2.1.6.1 paragraf } 1 \\
\text { dan 2). }\end{array}$ & $\mathrm{Q}_{18}, \mathrm{Q}_{19}$ \\
\hline & $\begin{array}{l}\text { (2018); Wulandari \& Iramani } \\
\text { (2014)). }\end{array}$ & $\begin{array}{l}\text { 2. Analisis terhadap informasi yang } \\
\text { tersedia (poin 2.1.6.1 paragraf 3). }\end{array}$ & $\mathrm{Q}_{20}, \mathrm{Q}_{21}, \mathrm{Q}_{22}$ \\
\hline & & $\begin{array}{l}\text { 3. Berfikir rasional (poin 2.1.6.1 paragraf } \\
\text { 4). }\end{array}$ & $\mathrm{Q}_{23}, \mathrm{Q}_{24}$ \\
\hline
\end{tabular}

Variabel dependen dan independen dalam penelitian ini diukur dengan menggunakan skala Likert. Penelitian ini menyediakan 4 alternatif pernyataan yang dikembangkan untuk menguji kekuatan persetujuan atau ketidaksetujuan responden. Adapun pilihan jawaban yang disediakan yaitu Sangat Setuju, Setuju, Tidak Setuju dan Sangat Tidak Setuju. 
Pemodifikasian pernyataan ini dimaksudkan untuk menghindari jawaban netral yang menandakan bahwa responden masih ragu-ragu terhadap pendapatnya sendiri.

Variabel dependen dan independen dalam penelitian ini diukur dengan menggunakan skala Likert. Penelitian ini menyediakan 4 alternatif pernyataan yang dikembangkan untuk menguji kekuatan persetujuan atau ketidaksetujuan responden. Adapun pilihan jawaban yang disediakan yaitu Sangat Setuju, Setuju, Tidak Setuju dan Sangat Tidak Setuju. Pemodifikasian pernyataan ini dimaksudkan untuk menghindari jawaban netral yang menandakan bahwa responden masih ragu-ragu terhadap pendapatnya sendiri.

\section{Sampel}

Sampel yang digunakan dalam penelitian ini berjumlah 119 investor anggota komunitas Investor Saham Pemula (ISP) di wilayah Jawa Timur. Ukuran sampel tersebut diperoleh dengan menggunakan teknik nonprobability sampling yaitu teknik purposive sampling. Adapun kriteria sampel dalam penelitian ini sesuai dengan penelitian yang dilakukan oleh (Djojopranoto \& Mahadwartha, 2016) yaitu:

1. Responden aktif yang melakukan trading minimal 3 kali transaksi dalam seminggu

2. Mampu mengambil keputusan sendiri tanpa bantuan dari broker

Jumlah sampel penelitian sebanyak 119 investor tersebut tersebar ke dalam beberapa daerah di Jawa Timur seperti Malang, Surabaya, Nganjuk, Lumajang, Sidoarjo, Mojokerto, Probolinggo, Pasuruan, Jember dan Kediri.

\section{Instrumen Penelitian}

Penelitian ini menggunakan data primer yang diperoleh secara langsung dari responden dengan menyebarkan kuesioner tertutup secara online pada aplikasi Whatsapp dan Telegram. Penelitian ini memilih kuesioner dikarenakan instrumen tersebut dianggap efisien sebagai alat pengumpul data mengingat wilayah penyebaran angket yang cukup luas yakni Jawa Timur. Kuesioner yang digunakan dalam penelitian ini terbagi menjadi 4 bagian. Bagian pertama terdiri dari identitas responden. Untuk menjaga kerahasiaan dari responden, hasil pengisian pada bagian ini tidak akan diungkap maupun dilampirkan, melainkan hanya diketahui oleh peneliti sebagai petunjuk pemisahan data. Bagian kedua hingga keempat kuesioner ini terdiri dari pernyataan atas setiap variabel. Adapun jumlah pernyataan dalam kuesioner penelitian ini adalah 24 butir pernyataan yang diukur dengan menggunakan skala likert dengan kategori jawaban Sangat Setuju, Setuju, Tidak Setuju dan Sangat Tidak Setuju. Selain itu, data primer penelitian juga didapat melalui proses wawancara secara langsung dengan narasumber dari perusahaan sekuritas di Indonesia.

\section{Teknik Analisis Data}

Analisis data dalam penelitian ini terdiri atas beberapa tahapan. Tahapan yang pertama yaitu melakukan pengujian instrumen penelitian untuk memastikan validitas dan reliabilitas instrumen penelitian. Uji validitas penelitian ini menggunakan Confirmatory Factor Analysis (CFA), sedangkan untuk uji reliabilitas menggunakan Cronbach's Alpha. Uji instrumen ini dilakukan pada 33 responden semu yakni mahasiswa pascasarjana Fakultas Ekonomi dan Bisnis Universitas Brawijaya karena dianggap telah menempuh mata kuliah manajemen investasi dan paham berinvestasi. Instrumen penelitian yang telah dinyatakan valid dan reliabel kemudian dapat disebarkan kepada responden asli atau sampel penelitian.

Setelah data dari responden asli terkumpul, tahapan selanjutnya melakukan uji asumsi klasik yaitu uji normalitas, uji heteroskedastisitas dan uji multikolinearitas. Kemudian data penelitian yang telah memenuhi asumsi klasik dianalisis menggunakan regresi linier berganda untuk menguji hipotesis. Uji regresi linier berganda dalam penelitian ini terdiri dari uji t, uji $F$ dan koefisien determinasi (R2). Analisis regresi linier berganda ini bertujuan untuk 
mengetahui seberapa jauh pengaruh perilaku representativeness bias dan herding effect terhadap pengambilan keputusan investasi rasional yang dinyatakan dalam persamaan sebagai berikut:

Keterangan:

$$
Y=\alpha-\beta_{1} X_{1}-\beta_{2} X_{2}+\varepsilon
$$

$\mathrm{Y} \quad=$ Pengambilan keputusan investasi rasional

a $=$ Konstanta

$\beta_{1}, \beta_{2}=$ Koefisien dari variabel independen

$\mathrm{X}_{1}, \mathrm{X}_{2}=$ Representativeness bias dan herding effect

$\mathrm{E}=$ Standar error

\section{HASIL DAN PEMBAHASAN}

Hasil uji validitas instrumen penelitian menggunakan Confirmatory Factor Analysis (CFA) menunjukkan bahwa terdapat 11 item pernyataan dinyatakan tidak valid karena memiliki nilai factor loading kurang dari 0,5. Sehingga, total pernyataan dalam kuesioner penelitian ini berjumlah 24 item yakni 6 item dari representativeness bias, 11 item dari herding effect dan 7 item dari keputusan investasi rasional. Uji reliabilitas untuk memastikan kehandalan instrumen penelitian menghasilkan nilai Cronbach's Alpha lebih dari 0,7 , artinya 24 item pernyataan yang tersisa dalam kuesioner dapat digunakan untuk memperoleh jawaban yang konsisten. Setelah data penelitian dinyatakan valid dan reliabel kemudian dilakukan pengujian hipotesis terhadap data yang dikumpulkan dari 119 responden.

Adapun hasil uji t terhadap hipotesis penelitian dengan menggunakan regresi linier berganda sebagai berikut:

Tabel 2. Hasil Analisis Uji t untuk Regresi Berganda

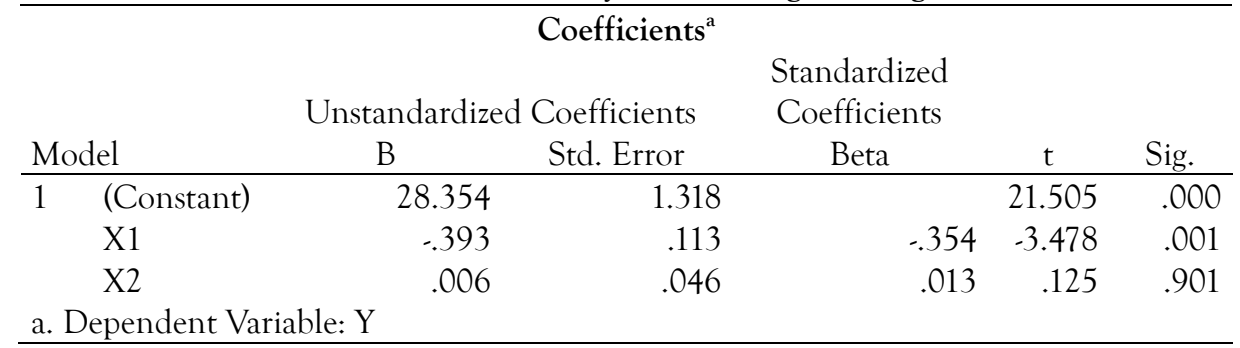

Sumber: Data Diolah

Berdasarkan tabel di atas dapat dirumuskan persamaan model regresi berganda sebagai berikut:

$$
\mathrm{Y}=28,354-0,393 \mathrm{X} 1+0,006 \mathrm{X} 2+\mathrm{e}
$$

Hasil analisis data menunjukkan nilai konstanta model regresi penelitian ini sebesar 28,354 , sehingga jika koefisien variabel bebas bernilai 0 , maka nilai pengambilan keputusan investasi rasional $(\mathrm{Y})$ sebesar 28,354. Variabel representativeness bias memiliki nilai signifikansi $(0,001)$ kurang dari 0,05 yang artinya representativeness bias $\left(\mathrm{X}_{1}\right)$ berpengaruh signifikan secara parsial terhadap pengambilan keputusan investasi rasional $(\mathrm{Y})$. Nilai koefisien variabel representativeness bias sebesar 0,393 dan bernilai negatif. Artinya, hubungan antar variabel bersifat berbanding terbalik sehingga setiap terdapat peningkatan 1 nilai pada variabel representatitiveness bias (X1) maka nilai variabel pengambilan keputusan investasi rasional menurun sebesar 0,393. Sedangkan, variabel herding effect memiliki nilai signifikansi $(0,901)$ lebih besar dari 0,05. Sehingga, dapat disimpulkan herding effect $\left(X_{2}\right)$ tidak berpengaruh secara parsial terhadap pengambilan keputusan investasi rasional $(\mathrm{Y})$. 
Uji F dimaksudkan untuk menguji signifikansi pengaruh beberapa variabel bebas secara simultan terhadap variabel terikat menghasilkan sebagai berikut:

Tabel 3. Hasil Analisis Uji F untuk Regresi Berganda

\begin{tabular}{|c|c|c|c|c|c|c|}
\hline \multicolumn{7}{|c|}{ ANOVA $^{a}$} \\
\hline \multicolumn{2}{|c|}{ Model } & $\begin{array}{l}\text { Sum of } \\
\text { Squares }\end{array}$ & df & $\begin{array}{l}\text { Mean } \\
\text { Square }\end{array}$ & $\mathrm{F}$ & Sig. \\
\hline \multirow[t]{3}{*}{1} & Regression & 101.974 & 2 & 50.987 & 7.471 & $.001^{\mathrm{b}}$ \\
\hline & Residual & 737.017 & 108 & 6.824 & & \\
\hline & Total & 838.991 & 110 & & & \\
\hline \multicolumn{3}{|c|}{$\begin{array}{l}\text { a. Dependent Variable: Y } \\
\text { X1 }\end{array}$} & & \multicolumn{3}{|c|}{ b. Predictors: (Constant), X2, } \\
\hline
\end{tabular}

Tabel di atas menunjukkan bahwa nilai Fhitung lebih besar dari nilai Ftabel (7,471 > $3,08)$ dan nilai signifikansi $(0,001)$ lebih kecil dari 0,05 . Sehingga, hasil uji $F$ menyatakan terdapat pengaruh variabel representativeness bias dan herding effect secara simultan terhadap pengambilan keputusan investasi rasional. Lebih lanjut, uji koefisien determinasi (R2) bertujuan untuk mengetahui seberapa baik suatu model dalam menjelaskan variabel terikat menghasilkan nilai sebagai berikut:

Tabel 4. Hasil Analisis Uji Koefisien Determinasi (R2) untuk Regresi Berganda Model Summary ${ }^{b}$

\begin{tabular}{|c|c|c|c|c|}
\hline Model & $\mathrm{R}$ & R Square & $\begin{array}{l}\text { Adjusted R } \\
\text { Square }\end{array}$ & $\begin{array}{l}\text { Std. Error of } \\
\text { the Estimate }\end{array}$ \\
\hline 1 & $.349^{\mathrm{a}}$ & .122 & .105 & 2.612 \\
\hline \multicolumn{5}{|c|}{ a. Predictors: (Constant), X2, X1 } \\
\hline \multicolumn{5}{|c|}{ b. Dependent Variable: Y } \\
\hline
\end{tabular}

Melalui tabel di atas dapat diketahui bahwa nilai $\mathrm{R}$ Square sebesar 0,122 atau mendekati angka 0 . Artinya, kemampuan variabel representativeness bias dan herding effect dalam menjelaskan variabel pengambilan keputusan investasi rasional sangat lemah. Sedangkan, nilai Adjusted R Square sebesar 0,105. Hal tersebut berarti variabel pengambilan keputusan investasi rasional hanya 10,5\% dapat dijelaskan oleh variabel representativeness bias dan herding effect, sisanya $89,5 \%$ dijelaskan oleh variabel-variabel lain.

\section{Perilaku Representativeness Bias terhadap Pengambilan Keputusan Investasi Rasional}

Berdasarkan hasil analisis regresi berganda yang telah dipaparkan pada bagian sebelumnya, diketahui bahwa perilaku representativeness bias berpengaruh negatif signifikan terhadap pengambilan keputusan investasi rasional. Hal ini berarti perilaku representativeness bias cenderung akan menurunkan kemampuan investor dalam menganalisis informasi secara rasional. Representativeness bias merupakan perilaku individu yang mendasarkan proses pengambilan keputusan investasi berdasarkan karakteristik yang dapat mewakili fenomena terkait, terlepas apakah karakteristik tersebut mempunyai kesamaan atau tidak. Heuristic Theory menjelaskan bahwa sistem kognitif manusia pada dasarnya memiliki kapasitas yang terbatas, sehingga untuk mengurangi kerja sistem kognitif secara tidak sadar individu menggunakan aturan jalan pintas guna menyederhanakan proses pengolahan informasi. Representativeness bias dianggap sebagai alternatif cara berfikir efesien yang dapat mereduksi jumlah serta kompleksitas informasi yang perlu dianalisis dalam mengevaluasi investasi. Namun, disamping menawarkan kemudahan dalam membuat 
keputusan investasi, perilaku ini justru mendorong timbulnya bias kognitif yang menyebabkan individu keliru dalam menilai realitas.

Representativeness bias merupakan perilaku individu yang mendasarkan penilaiannya pada pengalaman masa lalu. Pengalaman-pengalaman yang telah dialami individu secara otomatis membentuk kerangka mental yang dapat membantu mengorganisasikan informasi serta menuntun cara pemrosesannya. Sehingga, ketika investor dihadapkan pada situasi baru, maka cara untuk memahami situasi tersebut dengan memanggil skema yang dianggap sama. Hal tersebut diperkuat dengan argumen Maharani (2014) bahwa dalam kondisi lingkungan tidak pasti, individu tidak dapat mendasarkan keputusan pada analisis informasi yang akurat, melainkan pada apa yang telah terkonstruk dalam ingatannya. Lingkungan pasar yang tidak pasti menyebabkan investor mengalami ketakutan, kepanikan dan keserakahan, dimana kondisi mental seperti ini dapat mendistorsi kemampuan individu dalam menganalisis informasi secara rasional. Pada saat yang sama, investor berusaha menggunakan aturan jalan pintas untuk memperingan kerja sistem kognitif.

Perilaku representativeness bias mendorong individu terlalu percaya diri terhadap penilaian yang dibuat dibanding melakukan analisis secara mendalam mengenai fakta-fakta yang terjadi di pasar. Hal ini sependapat dengan pernyataan narasumber selaku manajer marketing salah satu perusahaan sekuritas di Indonesia bahwa:

"Namanya investor baru yang berlaku pengalaman. Dia beli untung kemudian posisi di atas dia gak jual, terus dia jual pas lagi turun dan beli lagi. Jangan-jangan ini naiknya kesini, saya tunggu aja".

Investor cenderung menyamakan kondisi yang dihadapi saat ini dengan kondisi masa lalu. Hal ini dikarenakan pola peristiwa yang terjadi secara berulang-ulang diyakini investor dapat terjadi kembali, akan tetapi harapan ini tidak beralasan karena tidak diimbangi dengan usaha analisis teknikal yang maksimal. Self-deciption tersebut pada akhirnya menghasilkan keputusan investasi yang secara sistematis salah, sebab individu meletakkan nilai terlalu tinggi pada pengalaman masa lalunya.

Perilaku representativeness bias juga mempengaruhi investor dalam memprediksi pengembalian yang diharapkan di masa depan. Perilaku ini mempersepsikan return masa lalu sebagai cerminan dari expected return di masa mendatang. Atas dasar pemikiran ini investor kemudian mengkategorikan saham yang memiliki kinerja masa lalu baik sebagai winner dan sebaliknya saham dengan kinerja masa lalu buruk sebagai loser, sehingga investor memilih saham winner yang memiliki prospek baik menurut penilaiannya. Akan tetapi, pembuatan kategori tersebut tidak didasari oleh analisis data yang memadai. Hal ini senada dengan pernyataan Singh (2012) bahwa investor hanya memfokuskan perhatiannya pada pola perubahan harga yang belakangan terjadi dan mengabaikan rata-rata perubahan harga dalam jangka waktu panjang. Individu cenderung mengasumsikan bahwa ukuran sampel kecil dapat merepresentasikan populasi. Investor hanya mengandalkan data kecil untuk mengevaluasi informasi yang direfleksikan dalam bentuk serangkaian data.

Selain itu, representativeness bias juga didefinisikan sebagai penilaian secara stereotype atau hanya berdasarkan kinerja kelompok dimana saham tersebut berada. Individu menyakini bahwa keanggotaan dari suatu kelompok semakin memungkinkan anggota kelompok memiliki karakteristik yang sama dengan kelompok tersebut. Apabila salah satu saham dalam sektor tertentu menguntungkan, maka investor dengan cepat menyimpulkan bahwa perusahaan lainnya dalam sektor yang sama juga menguntungkan. Akan tetapi, prediksi ini tidak akurat karena cenderung mengabaikan frekuensi keterjadian suatu peristiwa atau pola dalam populasi. Tversky \& Kahneman (1974) berpendapat bahwa stereotype bukan merupakan pendekatan yang tepat untuk menilai suatu fenomena, sebab 
penilaian atas probabilitas kebenarannya hanya berdasarkan kemiripan atau keterwakilan terhadap kelompok saja. Hal ini menyebabkan investor meniadakan analisis faktor-faktor penting yang dapat mempengaruhi kinerja saham dan akibatnya keputusan investasi yang dihasilkan menjadi bias. Hasil penelitian ini sejalan dengan penelitian yang dilakukan oleh Trang (2015), Dewi \& Kartini (2017) dan Khan et al. (2017), namun hasil penelitian ini tidak mendukung penelitian Hadi (2017).

\section{Perilaku Herding Effect terhadap Pengambilan Keputusan Investasi Rasional}

Perilaku herding effect merupakan kecenderungan investor mengikuti keputusan yang dibuat oleh investor lain untuk memperoleh petunjuk perdagangan di pasar modal. Hasil analisis regresi berganda dalam penelitian ini menunjukkan bahwa perilaku herding effect tidak memiliki pengaruh yang signifikan terhadap pengambilan keputusan investasi rasional. Tidak adanya pengaruh dalam penelitian ini menandakan bahwa investor lebih yakin terhadap hasil analisisnya sendiri daripada mengikuti keputusan yang diambil oleh investor lain. Hal ini sejalan dengan pernyataan narasumber bahwa:

"Keputusan investasi itu keputusan individu masing-masing investor, apakah lepas dari orang yang mengajaknya untuk masuk saham yang sama atau tidak.kan tergantung keputusan akhir. Kalau dia memutuskan untuk beli apakah dasar dari orang itu menyampaikan atau karena saya mau? Dia ngomong apa aja kalau saya gak mau tetap gak mau".

Keyakinan memiliki peranan yang cukup besar dalam menggerakkan keputusan investor, dimana keyakinan tersebut dijadikan pedoman untuk memutuskan tindakan apa yang seharusnya diambil ketika merespon kondisi pasar. Investor yang memiliki kepercayaan diri tinggi tidak mudah bereaksi terhadap perubahan yang terjadi di sekitarnya, melainkan lebih memilih untuk mengevaluasi terlebih dahulu peristiwa terkait berdasarkan pertimbangan-pertimbangan penting dan pengalaman yang dimiliki. Investor menganggap bahwa opini mayoritas investor di pasar tidak serta-merta dapat mengubah opini tersebut menjadi fakta. Oleh karena itu, investor mengandalkan keyakinan yang dihasilkan melalui proses nalarnya sendiri dibanding mengikuti keputusan investor lain.

Aksi menggiring pasar diawali oleh adanya spekulasi harga yang dibuat informed investors yang memiliki informasi dan skill analisis teknikal yang baik, kemudian uninformed investors menangkap informasi tersebut melalui perubahaan tren harga. Meskipun mengikuti petunjuk yang diberikan informed investors, investor privat tidak dapat memperoleh return seperti speculator, sebab informasi tersebut menjadi tidak berarti setelah direspon investor. Hal ini senada dengan hasil penelitian Fransiska, Sumani, Willy, \& Pangestu (2018) bahwa informasi yang disinyalkan speculator semakin lama nilainya semakin menurun sehingga kekuatan perubahan harga yang ditunjukkan juga semakin melemah. Apabila investor merespon lebih lambat dari speculator, maka pengembalian yang diperoleh akan lebih kecil atau bahkan rugi. Hal tersebut mendorong investor menjadi lebih selektif dalam memilih saham yang akan dimasukkan ke dalam portofolio investasinya. Oleh karena itu, keputusan investasi dibuat tidak semata-mata hanya mengikuti pergerakan harga saja, namun juga perlu membuat pertimbangan yang logis dan rasional. Hasil penelitian ini konsisten dengan penelitian yang dilakukan Trang (2015) dan Bakar \& Yi (2016). Akan tetapi, hasil penelitian ini tidak mendukung penelitian Ngoc (2014), Gupta, et al. (2014) \& Bhatt \& Pahuja (2016). 


\section{KESIMPULAN}

Berdasarkan hasil analisis data dalam penelitian ini dapat ditarik kesimpulan bahwa terdapat pengaruh negatif signifikan antara perilaku representativeness bias dan pengambilan keputusan investasi rasional. Artinya, semakin tinggi perilaku representativeness bias, maka semakin tidak rasional keputusan investasi yang dibuat. Sementara itu, variabel perilaku herding effect tidak berpengaruh signifikan terhadap pengambilan keputusan investasi rasional. Hal tersebut menandakan bahwa investor lebih mengandalkan informasi yang diperoleh melalui hasil nalarnya sendiri daripada mengikuti keputusan investor lain. Hasil penelitian ini turut berkontribusi membuktikan keberlakuan Heuristic Theory terutama dalam menjelaskan proses penyederhanaan analisis informasi melalui pengujian perilaku representativeness bias terhadap pengambilan keputusan investasi rasional. Selain itu, hasil penelitian ini juga dapat dijadikan sebagai bahan evaluasi dan masukkan bagi investor untuk lebih teliti dalam menganalisis informasi serta menjaga kondisi psikologi tetap stabil agar investasi yang dihasilkan mampu memberikan keuntungan yang maksimal. Namun demikian nilai Adjusted R Square penelitian ini hanya sebesar 0,105. Hal ini berarti perilaku representativeness bias dan herding effect hanya dapat menjelaskan keputusan investasi rasional sebesar 10,5\%, sehingga masih terdapat 89,5\% faktor-faktor lain yang dapat mempengaruhi pengambilan keputusan investasi. Fakfor-faktor tersebut diantaranya adalah informasi kinerja keuangan perusahaan.

Penelitian ini memiliki beberapa keterbatasan diantaranya yaitu uji validitas kuesioner dalam penelitian ini pada awalnya menggunakan Pearson Product-Moment Correlation. Akan tetapi, metode tersebut tidak dapat memberikan gambaran yang jelas mengenai indikator apa saja yang dapat membentuk konstruk, sehingga indikator variabel menjadi bias dan tidak dapat digunakan sebagai dasar pembahasan. Berdasarkan hasil penelitian dan keterbatasan dalam penelitian ini, dapat dilihat bahwa keputusan investasi dipengaruhi oleh berbagai faktor. Penelitian selanjutnya dapat melakukan pengujian terhadap informasi-informasi lain baik informasi keuangan maupun non keuangan yang mungkin dianggap rasional dan relevan bagi investor untuk pengambilan keputusan investasi.

\section{DAFTAR PUSTAKA}

Bakar, S., \& Yi, A. N. C. (2016). The Impact of Psychological Factors on Investors' Decision Making in Malaysian Stock Market: A Case of Klang Valley and Pahang. Procedia Economics and Finance, 35(October 2015), 319-328. https://doi.org/10.1016/s2212-5671(16)00040-x

Baron, R. A., \& Byrne, D. (2004). Psikologi Sosial Jilid 1. Jakarta: Erlangga.

Bhatt, A. K., \& Pahuja, C. K. K. (2016). Investigating Impact of Herd and Prospect Factors Influencing Individual " $\mathrm{s}$ Investment Decision. International Journal of Trend in Research and Development, 3(3), 427-432.

Chitra, K., \& Jayashree, T. (2014). Does Demographic Profile Create a Difference in the Investor Behavior? The International Journal of Business \& Management, 2(7).

Creswell, J. W. (2012). Research Design: Pendekatan Kualitatif, Kuantitatif, dan Mixed (Pustaka Pe). Yogyakarta.

Dewi, S. K., \& Kartini. (2017). Pengaruh Availability Bias, Loss Aversion Bias, dan Representativeness Bias Terhadap Pengambilan Keputusan Investasi. Forum Manajemen Indonesia (FMI) Ke-9, (November 2017), 135.

Djojopranoto, R. R., \& Mahadwartha, P. A. (2016). Pengujian Bias Perilaku: Gambler'S Fallacy, Halo Effect, Dan Familiarity Effect Di Pasar Modal Indonesia. Jurnal Akuntansi Dan Keuangan Indonesia, 13(2), 142-159. https://doi.org/10.21002/jaki.2016.08

Fama, E. F. (1970). Efficient Capital Markets : A Review of Theory and Empirical. The Journal of Finance, 25(2), 383-417. 
Fransiska, M., Sumani, Willy, \& Pangestu, S. (2018). Herding Behavior in Indonesian Investors. International Research Journal of Business Studies, 11(2), 129-143. https://doi.org/10.21632/irjbs.11.2.129-143

Ghalandari, K., \& Ghahremanpour, J. (2013). The effect of market variables and herding effect on investment decision as factor influencing investment performance in Iran. Journal of Basic and Applied Scientific Research, 3(3), 313-318.

Gumelar, G. (2018). Darmin Sebut Reaksi Investor Berlebihan Respons Krisis Turki. Retrieved from CNN Indonesia website:https://www.cnnindonesia.com/ekonomi/20180813132443. 532-321834/darmin-sebut-reaksi-investor-berlebihan-respons-krisis-turki

Gupta, E., Preetibedi, P., \& Mlakra, P. (2014). Efficient Market Hypothesis V/S Behavioural Finance. IOSR Journal of Business and Management, 16(4), 56-60. https://doi.org/10.9790/487x-16445660

Hadi, F. (2017). Impact of Biases on Perceived Market Efficiency : Case of Pakistani Financial Market. 8(1), 1-8.

Hinnant, C. H. (1998). The invention of Homo Oeconomicus: A reading of John Stuart Mill's "On the definition of political economy." Prose Studies, 21(3), 51-68. https://doi.org/10.1080/01440359808586653

Kahneman, D., \& Tversky, A. (1979). Prospect Theory: An Analysis of Decision under Risk. Econometrica, 47(2), 263-291. https://doi.org/10.2307/1914185

Kengatharan, L., \& Kengatharan, N. (2014). The Influence of Behavioral Factors in Making Investment Decisions and Performance: Study on Investors of Colombo Stock Exchange, Sri Lanka. Asian Journal of Finance \& Accounting, 6(1), 1. https://doi.org/10.5296/ajfa.v6i1.4893

Khan, H. H., Naz, I., Qureshi, F., \& Ghafoor, A. (2017). Heuristics and stock buying decision: Evidence from Malaysian and Pakistani stock markets. Borsa Istanbul Review, 17(2), 97-110. https://doi.org/10.1016/j.bir.2016.12.002

Kim, K. A., \& Nofsinger, J. R. (2008). Behavioral finance in Asia. Pacific Basin Finance Journal, 16(1-2), 1-7. https://doi.org/10.1016/j.pacfin.2007.04.001

Maharani, S. N. (2014). Rekonsiliasi Perseteruan Antara Efficient Market Hypothesis dan Behavioral Finance Melalui Perspektif Neuroeconomics. Jurnal Akuntansi Multiparadigma, $5(2)$.

Manuel, J., \& Mathew, G. G. (2017). Impact of Cognitive Biases in Investment Decisions of Individual Investors in Stock Market. International Journal of Engineering Technology, Management, and Applied Sciences, 5(6), 2349-4476.

Narullia, D., Subekti, I., Azizah, N., \& Purnamasari, F. (2019). Value Relevance of Corporate Social Responsibility Disclosure on Public Companies in ASEAN Countries. KnE Social Sciences, 3(11), 475. https://doi.org/10.18502/kss.v3i11.4027

Narullia, D., \& Subroto, B. (2018). Value Relevance of Accounting Information and Corporate Social Responsibility in Indonesia and Singapore. Jurnal Aplikasi Manajemen, 16(1), 9-19. https://doi.org/10.21776/ub.jam.2018.016.01.02

Ngoc, L. T. B. (2014). Behavior Pattern of Individual Investors in Stock Market. International Journal of Business and Management, 9(1), 1-16. https://doi.org/10.5539/ijbm.v9n1p1

Pradhana, R. W. (2018). Pengaruh Financial Literacy, Cognitive Bias, dan Emotional Bias terhadap Keputusan Investasi (Studi pada Investor Galeri Investasi Universitas Negeri Surabaya). Jurnal Ilmu Manajemen (JIM), 6(3), 108-117.

Rasheed, M. H., Rafique, A., Zahid, T., \& Akhtar, M. W. (2018). Factors influencing investor's decision making in Pakistan: moderating the role of locus of control. Review of Behavioral Finance.

Scott, W. R. (2015). Financial Accounting Theory (Seventh Ed). PEARSON Canada Inc. 
Singh, S. (2012). Investor Irrationality and Self-Defeating Behavior: Insights from Behavioral Finance. The Journal of Global Business Management, 8(1), 116-122. Retrieved from http://www.jgbm.org/page/16 Sudhir Singh.pdf

Statman, M. (2014). Behavioral finance: Finance with normal people. Borsa Istanbul Review, 14(2), 65-73. https://doi.org/10.1016/j.bir.2014.03.001

Trang, P. (2015). Behavioral factors affecting investment decision-making: The case of Ho Chi Minh Stock exchange (HOSE). Journal of Transportation Science and Technology, 14(2), $106-110$.

Tversky, A., \& Kahneman, D. (1974). Judgment under Uncertainty. Science, 185, 1124-1131. https://doi.org/10.1016/0022-1031(70)90052-1

Tversky, A., \& Kahneman, D. (1992). Advances in prospect theory: Cumulative representation of uncertainty. Journal of Risk and Uncertainty, 5(4), 297-323.

Wijayanto. (2018). Jatim Urutan 3 Jumlah Investor Pasar Modal. Retrieved from Radar Surabaya website: https://radarsurabaya.jawapos.com/read/2018/04/18/66040/jatim-urutan-3jumlah-investor-pasar-modal

Wulandari, D. A., \& Iramani, R. (2014). Studi Experienced Regret, Risk Tolerance, Overconfidance Dan Risk Perception Pada Pengambilan Keputusan Investasi. Journal of Business and Banking, 4(1), 55. https://doi.org/10.14414/jbb.v4i1.293 